\title{
Direct arylation polycondensation for the synthesis of bithiazole-based conjugated polymers and their physical properties
}

\author{
Junpei Kuwabara ${ }^{1}$, Masahiro Kuramochi ${ }^{1}$, Songlin Liu ${ }^{1}$, Takeshi Yasuda ${ }^{2}$ and Takaki Kanbara ${ }^{1}$
}

The reaction conditions for direct arylation polycondensation were investigated for the synthesis of bithiazole-based conjugated polymers, which have been difficult to synthesize under previous conditions owing to the low solubility of the product in the reaction solvent. The investigation revealed that the reaction with the $\operatorname{Pd}\left(\mathrm{PC}_{3}\right)_{2}$ precatalyst and $\mathrm{N}, \mathrm{N}$-diethylpropanamide (that is, reaction solvent) afforded three types of the bithiazole-based conjugated polymers with high molecular weights. These conditions also effectively suppressed the formation of structural defects, such as a non-alternating structure caused by homocoupling. The structure-property relationships of the obtained polymers were evaluated based on their absorption properties, energy levels, crystallinity and semiconducting properties. The highest occupied molecular orbital/lowest unoccupied molecular orbital levels reasonably reflect their chemical structure. The high crystallinity of the polymers was confirmed by X-ray diffraction analysis. These polymers tend to aggregate even in the solution state. Control of the aggregation characteristics was a key factor for increasing the power conversion efficiency of the organic photovoltaic devices that were fabricated from the polymers. This study expanded the application range of direct arylation polycondensation for the preparation of crystalline polymer materials.

Polymer Journal (2017) 49, 123-131; doi:10.1038/pj.2016.75; published online 7 September 2016

\section{INTRODUCTION}

Bithiazole derivatives are attractive aromatic units for optoelectronic materials owing to their planar structure, electron acceptor properties and strong intermolecular interactions. ${ }^{1}$ Bithiazole-based small molecules serve as high-performance n-type semiconducting materials for organic field-effect transistors. ${ }^{2} \pi$-Conjugated polymers bearing bithiazole units have also been reported as n-type semiconducting materials ${ }^{3}$ as well as p-type semiconducting materials for organic field-effect transistors $^{4,5}$ and organic photovoltaics (OPVs). ${ }^{1,6-8}$ Owing to the weak acceptor property of bithiazole units, bithiazole-based polymers have lower highest occupied molecular orbital (HOMO) levels than the corresponding thiophene-based polymers. The low HOMO level of the bithiazole-based polymer affords several advantages in terms of air stability and electron transport properties. ${ }^{1,3-5}$ In addition, intermolecular interactions between the $\mathrm{S}$ and $\mathrm{N}$ atoms suggest that the bithiazole-based polymers may have strong interchain interactions, which result in aggregation properties and high crystallinity.

These bithiazole-based polymers have been primarily synthesized via polycondensation using cross-coupling reactions, such as the Migita-Kosugi-Stille and Suzuki-Miyaura coupling reactions. ${ }^{1,9,10}$ However, the instability of the stannylated bithiazole monomer has led to the formation of a low molecular weight polymer. ${ }^{3,11}$ In recent years, polycondensation using a direct $\mathrm{C}-\mathrm{H}$ arylation reaction was developed as an alternative method for the synthesis of conjugated polymers. ${ }^{12-18}$ Because direct arylation polycondensation does not require organometallic monomers, this new method can avoid the preparation of stannylated monomers, which require caution in handling and have problems associated with instability. In fact, direct arylation polycondensation of bithiazole-based monomers has afforded a series of conjugated polymers with high molecular weights. ${ }^{19-22}$ In some cases, only low molecular weight polymers were obtained owing to the low solubility of the target polymers in the reaction solvent (that is, $N, N$-dimethylacetamide (DMAc)). ${ }^{21,22}$ To overcome this issue, investigation of the reaction conditions was the primary objective of this study. In addition, we evaluated the accuracy of the repeating structures of the polymers that were synthesized under the established reaction conditions. Finally, the structure-property relationships of the polymers were investigated based on their absorption properties, energy levels, crystallinity and semiconducting properties to provide insight into the bithiazole-based polymers.

\section{EXPERIMENTAL PROCEDURE}

Materials

$\mathrm{Pd}(\mathrm{OAc})_{2}$, chlorobenzene (CB), 1,8-diiodooctane (DIO) and other chemicals were received from commercial suppliers and used without further purification. $\mathrm{Pd}\left(\mathrm{PCy}_{3}\right)_{2}$ was purchased from Aldrich (St Louis, MO, USA) and stored under

\footnotetext{
${ }^{1}$ Tsukuba Research Center for Interdisciplinary Materials Science (TIMS), Graduate School of Pure and Applied Sciences, University of Tsukuba, Ibaraki, Japan and ${ }^{2}$ Research Center for Functional Materials, National Institute for Materials Science (NIMS), Ibaraki, Japan

Correspondence: Dr J Kuwabara or Professor T Kanbara, Tsukuba Research Center for Interdisciplinary Materials Science (TIMS), Graduate School of Pure and Applied Sciences, University of Tsukuba, 1-1-1 Tennodai, Tsukuba, Ibaraki 305-8573, Japan.

E-mail: kuwabara@ims.tsukuba.ac.jp or kanbara@ims.tsukuba.ac.jp

Received 23 May 2016; revised 8 July 2016; accepted 10 July 2016; published online 7 September 2016
} 
$\mathrm{N}_{2}$ atmosphere at $0{ }^{\circ} \mathrm{C}$. Anhydrous DMAc was purchased from Kanto Chemical (Tokyo, Japan) and used as a dry solvent. N,N-diethylpropanamide was dried over molecular sieves and degassed by freeze-pump-thaw cycles prior to use. 4,4'-Bis(2-octyldodecyl)-2,2'-bithiazole, ${ }^{21}$ 5,5'-dibromo-2,2'-bithiazole, ${ }^{23} 4,4^{\prime}$ dinonyl-2,2'-bithiazole ${ }^{24}$ and 2,6-dibromo-4,8-bis(2-octyldodecyloxy)benzo [1,2-b:4,5- $\left.b^{\prime}\right]$ dithiophene ${ }^{25}$ were prepared according to previously reported methods. The synthesis of 2,6-dibromo-4,8-bis(2-octyldodecyl)benzo[1,2-b: $4,5-b^{\prime}$ ] dithiophene is described in Supplementary Information. Poly(3,4-ethylenedioxythiophene)-poly(styrenesulfonate) (PEDOT:PSS, CLEVIOS P VP AI 4083) was purchased from Heraeus (Hanau,Germany). $\mathrm{PC}_{70} \mathrm{BM}$ (purity 99\%) was purchased from Solenne (Groningen, The Netherlands).

\section{General measurements and characterization}

The nuclear magnetic resonance (NMR) spectra were recorded on AVANCE-400 and AVANCE-600 NMR spectrometers (Bruker, Karlsruhe, Germany). Gel permeation chromatography (GPC) measurements were conducted using a prominence GPC system (SHIMADZU, Kyoto, Japan) that was equipped with polystyrene gel columns using $\mathrm{CHCl}_{3}$ as the eluent after calibration with polystyrene standards $\left(40^{\circ} \mathrm{C}\right)$. The high-temperature GPC measurements $\left(140^{\circ} \mathrm{C}\right)$ were conducted using a HLC-8321 GPC/HT (TOSOH, Tokyo, Japan) with $o$-dichlorobenzene (o-DCB) as the eluent after calibration with polystyrene standards. The matrix-assisted laser desorption/ionization mass (MALDI-TOF-MS) spectra were recorded on a MALDI TOF/TOF 5800 (AB SCIEX, Framingham, MA, USA)) in linear mode using dithranol as the matrix. The ultraviolet-visible (UV-Vis) absorption spectra were recorded on a V-630 spectrometer (JASCO, Tokyo, Japan). The X-ray diffraction (XRD) patterns were recorded at $298 \mathrm{~K}$ on a MultiFlex X-ray diffractometer with a $\mathrm{CuK \alpha}$ radiation source (Rigaku, Tokyo, Japan). The HOMO energy levels were estimated by photoelectron yield spectroscopy using an AC-3 spectrometer (Riken Keiki, Tokyo, Japan). The atomic force microscopic images were obtained using Nanocute (SII Nano Technology Inc., Tokyo, Japan). The thermal properties were measured on an EXSTAR TG/DTA6300 instrument (Hitachi High-Technologies Corporation, Tokyo, Japan). The density functional theory (DFT) calculations were performed at the B3LYP/6-31G(d) level with the Gaussian09 Rev. D.01 program (Gaussian, Inc., Wallingford, CT, USA). All of the manipulations for the reactions were performed under a nitrogen atmosphere using a glove box or standard Schlenk techniques. The NMR spectra and TGA curves are shown in Supplementary Figures S7-S14.

\section{Synthesis of P1}

A mixture of $\mathrm{Pd}\left(\mathrm{PCy}_{3}\right)_{2}(6.6 \mathrm{mg}, 0.010 \mathrm{mmol}), 1$-adamantanecarboxylic acid (10.6 mg, $0.059 \mathrm{mmol}), \mathrm{K}_{2} \mathrm{CO}_{3}(67.2 \mathrm{mg}, 0.49 \mathrm{mmol}), 5,5^{\prime}$-dibromo-2,2'bithiazole $(63.9 \mathrm{mg}, 0.20 \mathrm{mmol})$ and 4,4'-di(2-octyldodecyl)-2,2'-bithiazole $(143 \mathrm{mg}, 0.20 \mathrm{mmol})$ was stirred in $N, N$-diethylpropanamide $(2.0 \mathrm{ml})$ at $100{ }^{\circ} \mathrm{C}$ for $48 \mathrm{~h}$ under a nitrogen atmosphere. After cooling to room temperature, the mixture was poured into an aqueous solution of ethylenediaminetetraacetic acid disodium salt $(\mathrm{pH}=8)$. The suspension was stirred for $1 \mathrm{~h}$ at room temperature. The precipitates were separated by filtration and washed with a $10 \% \mathrm{HCl}$ solution, distilled water, methanol and hexane. The remaining solid was extracted with $\mathrm{CHCl}_{3}$ by sonication and stirring at room temperature. The solution was filtered, concentrated and reprecipitated into methanol. The precipitates were collected by filtration and dried under reduced pressure. P1 was isolated as a dark red solid in $43 \%$ yield as a hexane-insoluble and $\mathrm{CHCl}_{3}$-soluble fraction. $M_{\mathrm{n}}=35000, M_{\mathrm{w}} / M_{\mathrm{n}}=3.21 .{ }^{1} \mathrm{H} \mathrm{NMR}(600 \mathrm{MHz}$, $\left.\mathrm{C}_{2} \mathrm{D}_{2} \mathrm{Cl}_{4}, 373 \mathrm{~K}\right): \delta 7.94(\mathrm{~s}, 2 \mathrm{H}), 2.89(\mathrm{br}, 4 \mathrm{H}), 2.05(\mathrm{~m}, 2 \mathrm{H}), 1.43-1.18$ (br, $64 \mathrm{H}), 0.85$ (m, 12H). ${ }^{13} \mathrm{C}\left\{{ }^{1} \mathrm{H}\right\}$ NMR (150 MHz, $\left.\mathrm{C}_{2} \mathrm{D}_{2} \mathrm{Cl}_{4}, 373 \mathrm{~K}\right): \delta 161.36$, $159.11,156.92,143.56,131.03,124.25,38.35,35.48,34.31,34.09,32.06,30.16$, $29.79,29.74,29.43,26.95,22.76,14.11$ (8 signals of the alkyl group were overlapped). Anal. Calcd. for $\mathrm{C}_{52} \mathrm{H}_{84} \mathrm{~N}_{4} \mathrm{~S}_{4}$ : C, 69.90; H, 9.48; N, 6.27; S, 14.35; Br, 0.00. Found: C, 69.05; H, 9.86; N, 6.32; S, 14.42; Br, 0.14 .

\section{Synthesis of $\mathbf{P 2}$}

A mixture of $\mathrm{Pd}\left(\mathrm{PCy}_{3}\right)_{2}(5.0 \mathrm{mg}, 0.0075 \mathrm{mmol}), 1$-adamantanecarboxylic acid (8.1 mg, $0.045 \mathrm{mmol}), \mathrm{K}_{2} \mathrm{CO}_{3}(51.8 \mathrm{mg}, 0.38 \mathrm{mmol}), 2,6$-dibromo-4,8-bis $(2-$ octyldodecyloxy) benzo[1, 2-b:4,5- $\left.b^{\prime}\right]$ dithiophene $(141.2 \mathrm{mg}, 0.15 \mathrm{mmol})$ and 4,4'-dinonyl-2,2'-bithiazole ( $63.1 \mathrm{mg}, 0.15 \mathrm{mmol}$ ) in $\mathrm{N}, \mathrm{N}$-diethylpropanamide
$(1.5 \mathrm{~mL})$ was stirred at $100{ }^{\circ} \mathrm{C}$ for $48 \mathrm{~h}$ under a nitrogen atmosphere. Then a solution of $4,4^{\prime}$-dinonyl-2,2'-bithiazole $(31.5 \mathrm{mg}, 0.075 \mathrm{mmol})$ in $\mathrm{N}, \mathrm{N}$-diethylpropanamide $(1.5 \mathrm{ml})$ was added to the reaction mixture. After the reaction proceeded at $100{ }^{\circ} \mathrm{C}$ for $24 \mathrm{~h}, \mathbf{P} 2$ was isolated as a hexane-insoluble and $\mathrm{CHCl}_{3^{-}}$ soluble fraction in $51 \%$ yield by the same purification procedure that was used for P1. $M_{\mathrm{n}}=47000, M_{\mathrm{w}} / M_{\mathrm{n}}=3.61 .{ }^{1} \mathrm{H}$ NMR $\left(600 \mathrm{MHz}, \mathrm{C}_{2} \mathrm{D}_{2} \mathrm{Cl}_{4}, 373 \mathrm{~K}\right)$ : $\delta 7.58(\mathrm{~s}, 2 \mathrm{H}), 4.26(\mathrm{br}, 4 \mathrm{H}), 3.07$ (br, $4 \mathrm{H}), 1.97-1.82(\mathrm{br}, 4 \mathrm{H}), 1.65(\mathrm{br}, 2 \mathrm{H})$, $1.57-1.17(\mathrm{~m}, 88 \mathrm{H}) 0.86(\mathrm{~m}, 18 \mathrm{H}) .{ }^{13} \mathrm{C}\left\{{ }^{1} \mathrm{H}\right\} \mathrm{NMR}\left(150 \mathrm{MHz}, \mathrm{C}_{2} \mathrm{D}_{2} \mathrm{Cl}_{4}, 373 \mathrm{~K}\right)$ : $\delta 159.01,156.50,144.59,133.38,132.30,130.08,128.14,120.64,77.17,39.81$, $32.05,31.91,30.89,30.28,29.84,29.78,29.71,29.68,29.56,29.44,27.35,22.75$, 14.09 (14 signals of the alkyl group were overlapped). Anal. Calcd. for $\mathrm{C}_{74} \mathrm{H}_{122} \mathrm{~N}_{2} \mathrm{O}_{2} \mathrm{~S}_{4}$ : C, 74.07; H, 10.25; N, 2.33; S, 10.69; $\mathrm{Br}, 0.00$. Found: C, 72.94; H, 10.43; N, 2.45; S, 10.56; Br, 0.11 .

\section{Synthesis of P3}

P3 was synthesized using the same procedure as that used for P2 on a $0.18 \mathrm{mmol}$ scale with 2,6-dibromo-4,8-bis(2-octyldodecyl)benzo[1,2-b:4,5- $\left.b^{\prime}\right]$ dithiophene (163.9 mg, $0.18 \mathrm{mmol}$ ) rather than 2,7-dibromo-4,8-bis(2-octyldodecyloxy)benzo[1,2-b:4,5- $\left.b^{\prime}\right]$ dithiophene. P3 was isolated as a hexaneinsoluble and $\mathrm{CHCl}_{3}$-soluble fraction in $85 \%$ yield. $M_{\mathrm{n}}=49000, M_{\mathrm{w}} /$ $M_{\mathrm{n}}=4.61 .{ }^{1} \mathrm{H}$ NMR $\left(600 \mathrm{MHz}, \mathrm{C}_{2} \mathrm{D}_{2} \mathrm{Cl}_{4}, 373 \mathrm{~K}\right): \delta 7.57$ (s, 2H), 3.09 (br, $8 \mathrm{H}), 2.13(\mathrm{br}, 2 \mathrm{H}), 1.90(\mathrm{br}, 4 \mathrm{H}), 1.53-1.15(\mathrm{~m}, 88 \mathrm{H}), 0.855(\mathrm{~m}, 18 \mathrm{H}) .{ }^{13} \mathrm{C}\left\{{ }^{1} \mathrm{H}\right\}$ NMR (150 MHz, $\left.\mathrm{C}_{2} \mathrm{D}_{2} \mathrm{Cl}_{4}, 373 \mathrm{~K}\right): \delta 158.83,156.18,139.11,137.59,133.22$, $128.81,128.65,122.50,39.22,38.86,34.77,32.05,30.99,30.20,29.78,29.73$, $29.69,29.59,29.43,27.12,22.75 .14 .08$ (15 signals of the alkyl group were overlapped). Anal. Calcd. for $\mathrm{C}_{74} \mathrm{H}_{122} \mathrm{~N}_{2} \mathrm{~S}_{4}$ : C, 76.09; H, 10.53; N, 2.40; S, 10.98 ; $\mathrm{Br}, 0.00$. Found: $\mathrm{C}, 75.40 ; \mathrm{H}, 10.88 ; \mathrm{N}, 2.39 ; \mathrm{S}, 11.33 ; \mathrm{Br}, 0.00$.

\section{Fabrication and characterization of OPV cells}

The OPV cells were fabricated in the following configuration: ITO/PEDOT: PSS/bulk heterojunction (BHJ) layer/LiF/Al. The patterned ITO (conductivity: $10 \Omega$ per square) glass was precleaned in an ultrasonic bath containing acetone and ethanol and then treated in an ultraviolet-ozone chamber. A thin layer $(40 \mathrm{~nm})$ of PEDOT:PSS was spin-coated onto the ITO at 3000 r.p.m. and airdried at $110^{\circ} \mathrm{C}$ for $10 \mathrm{~min}$ on a hot plate. Then the substrate was transferred to a $\mathrm{N}_{2}$-filled glove box where it was re-dried at $110^{\circ} \mathrm{C}$ for $10 \mathrm{~min}$ on a hot plate. A CB solution (3\% DIO) consisting of $\mathbf{P 2}$ and $\mathrm{PC}_{70} \mathrm{BM}$ blended in a 1:2 or 1:4 ratio was subsequently spin-coated onto the PEDOT:PSS surface to form the $\mathrm{BHJ}$ layer. The substrates with the $\mathrm{BHJ}$ layers were dried for $10 \mathrm{~min}$ at $110^{\circ} \mathrm{C}$ for the film spin-casted from the CB solution. Then $\mathrm{LiF}(1 \mathrm{~nm})$ and $\mathrm{Al}(80 \mathrm{~nm})$ were deposited onto the active layer by conventional thermal evaporation at a chamber pressure lower than $5 \times 10^{-4} \mathrm{~Pa}$, which provided the devices with an active area of $5 \times 2 \mathrm{~mm}^{2}$. The thicknesses of the BHJ and PEDOT:PSS layers were measured using an automatic microfigure measuring instrument (SURFCORDER ET200, Kosaka Laboratory, Ltd., Tokyo, Japan). The current density-voltage $(J-V)$ curves were measured using an ADCMT 6244 DC voltage current source/monitor under AM 1.5 solar-simulated light irradiation $\left(100 \mathrm{~mW} \mathrm{~cm}^{-2}\right.$ ) (OTENTO-SUN III, Bunkoh-Keiki Co., Ltd., Tokyo, Japan). The external quantum efficiency (EQE) and the internal quantum efficiency (IQE) were measured using an SM-250 system (Bunkoh-Keiki Co., Ltd.) with an integrating sphere to determine the reflectance $(R)$ of the BHJ OPVs to estimate $\mathrm{IQE}=\mathrm{EQE} /(1-R)$.

\section{RESULTS AND DISCUSSION \\ Optimization of reaction conditions}

To investigate the synthetic conditions for a conjugated polymer with low solubility, direct arylation polycondensation of 4,4'-bis(2-octyldodecyl)-2,2'-bithiazole with 5,5'-dibromo-2,2'-bithiazole was selected as the target reaction. The corresponding polymer (P1) is expected to have a low solubility in polar solvents owing to its planar structure and the interchain interactions of the bithiazole units (Table 1). ${ }^{26,27}$ Under the previously reported conditions using DMAc, ${ }^{19-22}$ only oligomeric products were obtained, as expected (Entry 1, Table 1). In Entry 2, a reaction at a higher temperature $\left(120^{\circ} \mathrm{C}\right)$ was conducted to increase the reaction rate and amount of dissolved polymer during the 

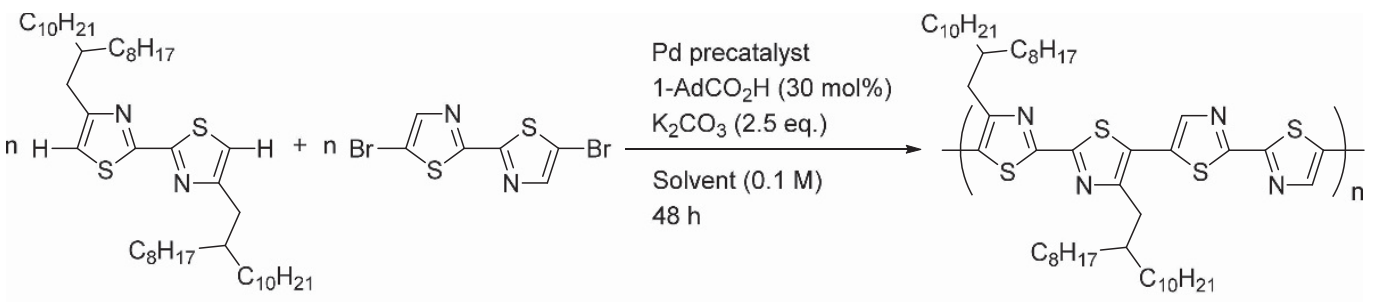

P1

\begin{tabular}{|c|c|c|c|c|c|c|c|}
\hline \multirow[b]{2}{*}{ Entry } & \multirow[b]{2}{*}{ Catalyst } & \multirow[b]{2}{*}{ Temp., ${ }^{\circ} \mathrm{C}$} & \multirow[b]{2}{*}{ Solvent } & \multicolumn{2}{|c|}{ Hexane soluble partc } & \multicolumn{2}{|c|}{$\mathrm{CHCl}_{3}$ soluble part } \\
\hline & & & & Yield, \% & $\mathrm{M}_{n}^{\mathrm{e}}\left(\mathrm{M}_{w} \mathrm{M}_{n}\right)$ & Yield, \% & $\mathrm{M}_{n}^{\mathrm{e}}\left(\mathrm{M}_{w} \mathrm{M}_{n}\right)$ \\
\hline 1 & $\mathrm{Pd}(\mathrm{OAc})_{2}^{f}$ & 100 & DMAC & 79 & $2700(1.19)$ & & \\
\hline 2 & $\mathrm{Pd}\left(\mathrm{PAr}_{3}\right)_{3} \mathrm{~g}$ & 120 & DMAC & 86 & $6000(1.88)$ & & \\
\hline 3 & $\mathrm{Pd}\left(\mathrm{PAr}_{3}\right)_{3} \mathrm{~g}$ & 120 & DMAc/m-xylene ${ }^{h}$ & 77 & $5300(2.28)$ & & \\
\hline 4 & $\mathrm{Pd}\left(\mathrm{PAr}_{3}\right)_{3} \mathrm{~g}$ & 120 & DEPA & 20 & $6000(2.52)$ & 62 & 17000 (2.86) \\
\hline 5 & $\mathrm{Pd}\left(\mathrm{Pt}-\mathrm{Bu}_{3}\right)_{2}$ & 120 & DEPA & 99 & $12000(2.80)$ & & \\
\hline 6 & $\mathrm{Pd}\left(\mathrm{PCy}_{3}\right)_{2}$ & 120 & DEPA & 52 & 11000 (3.34) & 44 & $26000(3.01)$ \\
\hline 7 & $\mathrm{Pd}\left(\mathrm{PC}_{3}\right)_{2}$ & 100 & DEPA & 42 & $18000(2.85)$ & 43 & $35000(3.21)$ \\
\hline 8 & $\mathrm{Pd}\left(\mathrm{PCy}_{3}\right)_{2}$ & 90 & DEPA & 57 & $19000(1.40)$ & & \\
\hline
\end{tabular}

aReactions were conducted using a Pd precatalyst (5 mol\%), 1- $\mathrm{AdCOOH}$ (30 mol\%), and $\mathrm{K}_{2} \mathrm{CO}_{3}$ (2.5 equiv).

bDAc $=N, N$-dimethylacetamide. $\mathrm{DEPA}=N, N$-diethylpropanamide.

${ }^{c}$ Methanol-insoluble and hexane-soluble fraction.

${ }^{d}$ Hexane-insoluble and $\mathrm{CHCl}_{3}$-soluble fraction.

eEstimated by GPC calibrated with polystyrene standards using $\mathrm{CHCl}_{3}$ as an eluent at $40{ }^{\circ} \mathrm{C}$.

$f_{2} 2 \mathrm{~mol} \%$ of $\mathrm{Pd}$ precatalyst.

${ }_{\text {gPAr }}=$ tris[3,5-bis(trifluoromethyl)phenyl] phosphine.

${ }^{\mathrm{h}} 1: 1$ mixture of DMAc and $m$-xylene.

reaction. In this reaction, a $\operatorname{Pd}(0)$ precatalyst with phosphine ligands was used to stabilize the Pd catalyst at high temperatures rather than using the reported phosphine-free catalyst. ${ }^{13}$ The molecular weight of the obtained polymer increased to 6000 (Entry 2) but the product was still soluble in hexane at room temperature. The addition of an aromatic solvent (that is, $m$-xylene) did not improve the molecular weight (Entry 3). Upon changing the solvent from DMAc to $\mathrm{N}, \mathrm{N}$-diethylpropanamide, the reaction afforded a hexane-insoluble product $(62 \%)$, which is a relatively high molecular weight fraction (Entry 4). With regards to the $\mathrm{Pd}(0)$ precatalyst, $\mathrm{Pd}\left(\mathrm{PCy}_{3}\right)_{2}$ was a suitable precursor for this reaction (Entries 4-6). In $N, N$-diethylpropanamide, reaction at $100^{\circ} \mathrm{C}$ provided a high molecular weight polymer with $M_{\mathrm{n}}=35000$ (Entry 7). A reaction temperature of $90^{\circ}$ $\mathrm{C}$ was insufficient for the formation of a high molecular weight polymer (Entry 8). Based on these results, the reaction conditions used for Entry 7 were determined to be the most suitable for the synthesis of $\mathbf{P 1}$ in a polar solvent. $\mathrm{PCy}_{3}$ has been reported to be an efficient supporting ligand for $\mathrm{Pd}$ catalysts in direct arylation reactions. ${ }^{28}$ The use of a $\operatorname{Pd}(0)$ precursor (that is, $\mathrm{Pd}\left(\mathrm{PCy}_{3}\right)_{2}$ ) rather than a $\mathrm{Pd}(\mathrm{II})$ precursor may lead to a high initiation efficiency in the catalysis. ${ }^{29} \mathrm{~N}$, $\mathrm{N}$-diethylpropanamide exhibited better solubilizing properties to P1 than DMAc at $100^{\circ} \mathrm{C}$, which was most likely due to the additional methylene moieties in $N, N$-diethylpropanamide (Supplementary Figure S1). The high solubilizing property of $N, N$-diethylpropanamide to $\mathbf{P 1}$ results in the formation of a high molecular weight polymer. Rudenko and Thompson ${ }^{30}$ also reported that N,N-diethylpropanamide was available in the synthesis of poly(3-hexylthiophene) using a direct arylation reaction. Toluene was not an appropriate solvent for this reaction system (Supplementary Table S1) even though toluene was utilized for direct arylation polycondensation of several electron-deficient monomers. ${ }^{31,32}$ A high-temperature GPC measurement $\left(140{ }^{\circ} \mathrm{C}\right)$ for the sample obtained from Entry 7 revealed a lower molecular weight $\left(M_{\mathrm{n}}=22000\right)$ than that obtained at $40^{\circ} \mathrm{C}$ $\left(M_{\mathrm{n}}=35000\right)$. This observation indicates aggregation of P1 at approximately room temperature. The aggregation behavior was evaluated by UV-Vis absorption spectroscopy, as described later.

\section{Characterization of the polymer structure}

The structure of $\mathbf{P 1}$ was evaluated using ${ }^{1} \mathrm{H}$ NMR and MALDI-TOFMS. Figure 1 shows the ${ }^{1} \mathrm{H}$ NMR spectrum of $\mathbf{P} \mathbf{1}$ that was obtained from Entry 7 in Table 1. In addition to the signals corresponding to the repeating unit $(7.94,2.89$ and 2.05 p.p.m.), signals corresponding to the terminal 4,4'-bis(2-octyldodecyl)bithiazole unit were observed at $6.94,2.75$ and 1.84 p.p.m. The small signal at 8.01 p.p.m. can be assigned to the linkage of the non-substituted bithiazole unit, which was estimated from the chemical shift of 5,5'-bithiazole. ${ }^{33}$ The nonalternating structure was caused by a homocoupling reaction of the $\mathrm{C}$-Br moieties of 5,5'-dibromo-2,2'-bithiazole, which is a common side reaction in direct arylation polycondensations. ${ }^{34-36}$ The signal intensity corresponding to the homocoupling defect depends on the reaction conditions (Supplementary Figure S2). The polymer from Entry 7 exhibited a relatively small amount of defects compared with those from Entries 4 and 6 (Table 1). These results indicate that the use of $\mathrm{PCy}_{3}$ and a low reaction temperature suppress the side reaction. In direct arylation, the homocoupling reaction of arylbromide is considered to occur via the transmetalation of aryl-Pd intermediates after oxidative addition of the arylbromide. ${ }^{29,37} \mathrm{PCy}_{3}$ may suppress the undesired transmetalation of the intermediates owing to its bulkiness and strong coordination ability. By evaluating the side reaction, the MALDI-TOF-MS results exhibited similar trends to the results from 

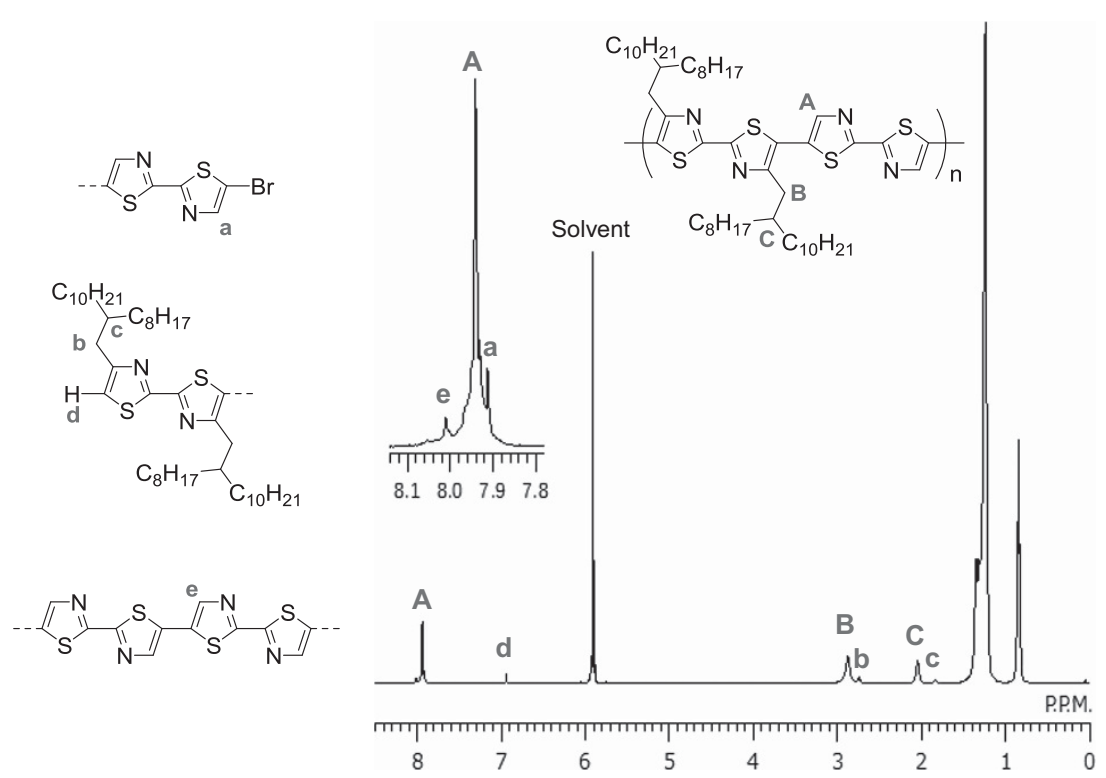

Figure $1{ }^{1} \mathrm{H}$ NMR spectrum of $\mathbf{P} 1$ (Entry 7 in Table 1) $\left(600 \mathrm{MHz}, \mathrm{C}_{2} \mathrm{D}_{2} \mathrm{Cl}_{4}, 373 \mathrm{~K}\right)$. A full color version of this figure is available at Polymer Journal online.

Table 2 Synthesis of P2 and P3

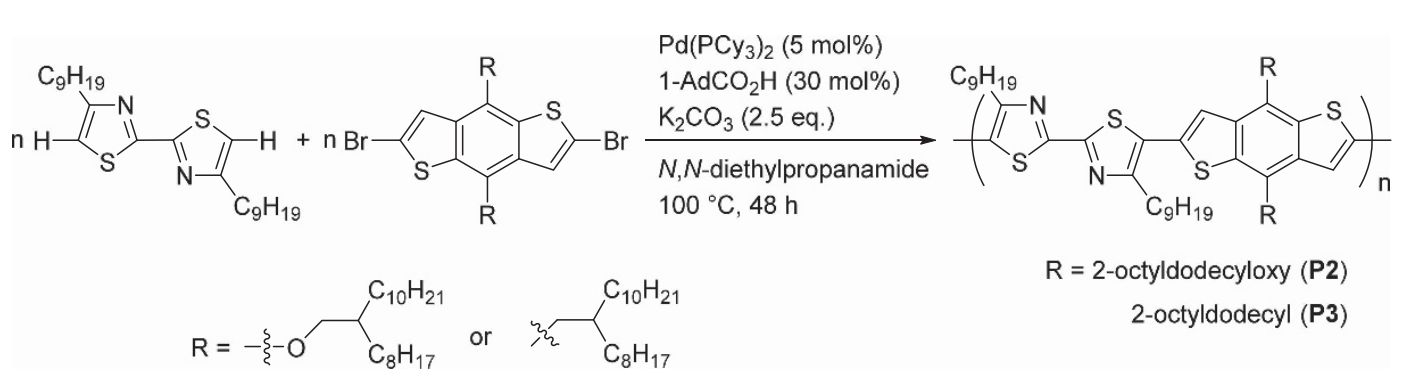

\begin{tabular}{|c|c|c|c|c|c|c|}
\hline Polymer & $\mathrm{R}$ & Yield, \% & $\mathrm{M}_{n}^{\mathrm{c}}\left(\mathrm{M}_{w} \mathrm{M}_{n}\right)$ & Yield, \% & $\mathrm{M}_{n}^{\mathrm{c}}\left(\mathrm{M}_{w} \mathrm{M}_{n}\right)$ & $\mathrm{M}_{n}^{\mathrm{d}}\left(\mathrm{M}_{w} \mathrm{M}_{n}\right)$ \\
\hline P3 & 2-Octyldodecyl & 10 & $15000(1.30)$ & 85 & $49000(4.61)$ & 28000 (2.49) \\
\hline
\end{tabular}

${ }^{a}$ Methanol-insoluble and hexane-soluble fraction.

bHexane-insoluble and $\mathrm{CHCl}_{3}$-soluble fraction.

cEstimated by GPC calibrated with polystyrene standards using $\mathrm{CHCl}_{3}$ as an eluent at $40{ }^{\circ} \mathrm{C}$

dEstimated by GPC calibrated with polystyrene standards using o-DCB as an eluent at $1400^{\circ} \mathrm{C}$.

eInsoluble products in $\mathrm{CHCl}_{3}$ were also obtained.

${ }^{1} \mathrm{H}$ NMR. The mass spectrum of the polymer from Entry 7 exhibited relatively low intensity peaks that corresponded to the defect structure (Supplementary Figure S3). The structure from the C-H/C-H homocoupling was also detected in the mass spectrum even though the ${ }^{1} \mathrm{H}$ NMR spectrum did not indicate the presence of this structure, which was most likely due to signals overlapping with those of the terminal structures.

\section{Synthesis of donor-acceptor (D-A) polymers}

Based on the established reaction conditions, bithiazole-based D-A polymers were synthesized via direct arylation of $4,4^{\prime}$-dinonyl-2,2'bithiazole with dibromobenzodithiophene derivatives to confirm the application range of the reaction conditions (Table 2). 2-Octyldodecyloxy- and 2-octyldodecyl-substituted dibromobenzodithiophenes were selected for preparation of $\mathrm{D}-\mathrm{A}$ polymers with different electronic properties. Both of the reactions with 2-octyldodecyloxyand 2-octyldodecyl-substituted dibromobenzodithiophenes afforded high molecular weight polymers (P2 and $\mathbf{P 3}$ ) in reasonable yields. For 2-octyldodecyloxy-substituted dibromobenzodithiophene, a small amount of $\mathrm{CHCl}_{3}$-insoluble products was obtained, which was most likely due to the low solubility caused by stronger interchain D-A interactions. Previous reports have demonstrated that a polycondensation reaction using Stille cross-coupling can afford an analogous polymer to P2 with a molecular weight of $7000 .^{7}$ The higher molecular 


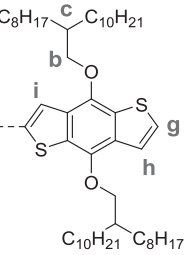<smiles>CCCCc1nc(-c2nc(CCC)c(C)s2)sc1C</smiles>

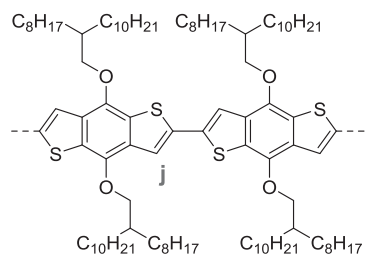

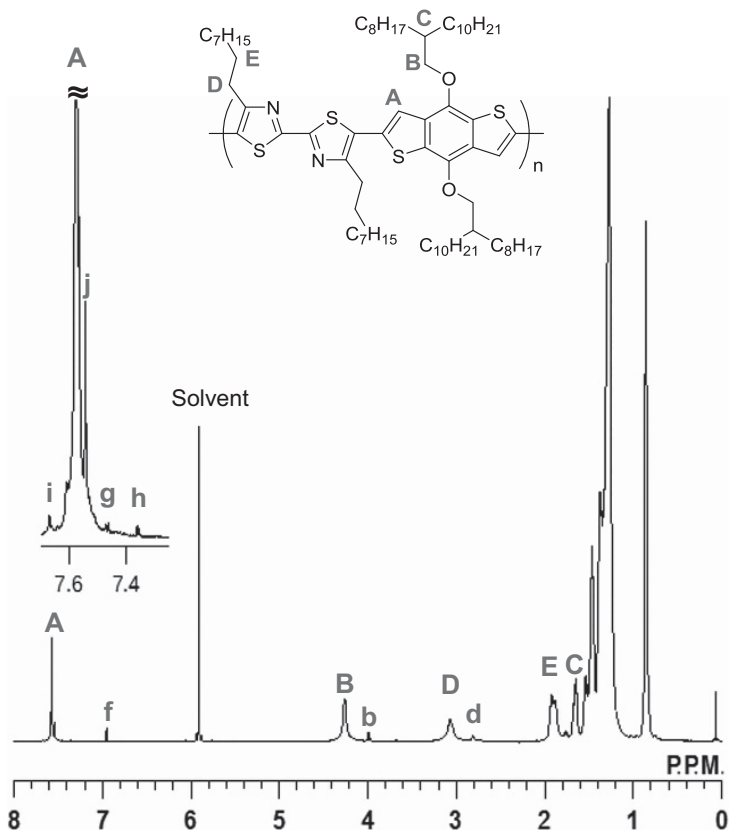

Figure $2{ }^{1} \mathrm{H}$ NMR spectrum of $\mathbf{P} 2\left(600 \mathrm{MHz}, \mathrm{C}_{2} \mathrm{D}_{2} \mathrm{Cl}_{4}, 373 \mathrm{~K}\right)$. A full color version of this figure is available at Polymer Journal online.

weight of $\mathbf{P 2}$ confirms that the established reaction conditions are useful for the synthesis of D-A polymers. Recently, Wakioka et al. ${ }^{38}$ reported the direct arylation polycondensation of a bithiazole monomer in tetrahydrofuran using their original catalytic system. Because this reaction also afforded a high molecular weight polymer, tetrahydrofuran is another option for the synthesis of bithiazole-based polymers.

The ${ }^{1} \mathrm{H}$ NMR spectrum of $\mathbf{P} 2$ contains relatively small signals for the terminal bithiazole structure compared with that for $\mathbf{P 1}$ owing to the high molecular weight of P2 (Figure 2). Three signals corresponding to the debrominated benzodithiophene terminal were observed at 7.67, 7.46 and 7.36 p.p.m. with a reasonable coupling pattern. The homocoupled structure of the benzodithiophene unit was also detected at 7.54 p.p.m. with a low intensity signal. ${ }^{39}$ In P3, similar signal patterns were observed in the ${ }^{1} \mathrm{H}$ NMR spectrum (Supplementary Figure S4). The MALDI-TOF-MS spectra indicated that alternative structures were dominant in both P2 and P3 (Supplementary Figures S5 and S6).

\section{Absorption properties}

The absorption maxima of P1-P3 appeared at approximately $500 \mathrm{~nm}$ in the solution state (Figures $3 \mathrm{a}-\mathrm{c}$ and Table 3 ). These absorption bands are associated with shoulders in a longer wavelength region. The shoulders may result from aggregation of the polymer in solution because time-dependent (TD)-DFT calculations for model compounds of P1-P3 did not predict transitions in the long wavelength region (Figure 4). The aggregation hypothesis is also supported by enhancement of the shoulder bands in the film state. To investigate the aggregation behavior, variable temperature absorption spectra were measured from 30 to $80^{\circ} \mathrm{C}$ (Figures $3 \mathrm{~d}-\mathrm{f}$ ). These spectra exhibited blue shifts of the absorption at high temperatures, which confirms the dissociation of aggregates. ${ }^{40}$ The shapes of the absorption spectra at $80^{\circ} \mathrm{C}$ are in good agreement with those of the estimated absorption spectra that were predicted using TD-DFT calculations (Figure 4). At $80^{\circ} \mathrm{C}, \mathbf{P 1}-\mathbf{P 3}$ possess similar absorption maxima even though $\mathbf{P} 2$ and P3 were expected to exhibit long-wavelength absorption compared with that of $\mathbf{P 1}$ owing to the D-A structures of $\mathbf{P} 2$ and P3. The weak acceptor property of the bithiazole unit may result in a small contribution from charge transfer absorption. ${ }^{21}$ Indeed, the TD-DFT calculations predicted a large contribution from a $\pi-\pi^{\star}$ transition from the HOMO to the lowest unoccupied molecular orbital (LUMO) in each polymer rather than a charge transfer transition (Figure 4).

\section{Physical properties}

The physical properties of P1-P3 are summarized in Table 4. Despite the similar absorption properties and band gaps in P1-P3, the energy levels reasonably reflect their chemical structures (Supplementary Figure S17). ${ }^{21,41}$ The results from photoelectron yield spectroscopy indicated that P1 had a lower HOMO level than those of P2 and P3 owing to the acceptor-acceptor structure of $\mathbf{P 1}$. The presence of an electron-donating oxygen atom in the side chain of $\mathbf{P} \mathbf{2}$ contributes to a slightly higher HOMO level compared with that of P3. To evaluate the crystallinity of the film state, X-ray diffraction analysis was performed on P1-P3 before and after annealing at $200{ }^{\circ} \mathrm{C}$ (Figure 5,Table 4). In all of the polymers, the annealing treatments sharpened the diffraction peaks. After annealing, P1 exhibited diffraction peaks that corresponded to a lamellar structure up to the fourth order. A diffraction peak corresponding to a $\pi-\pi$ stacking structure was not detected. Similar diffraction patterns were reported in bithiazole-rich conjugated polymers. ${ }^{4,5,27}$ In contrast, $\mathbf{P} 2$ exhibited a strong diffraction peak in the high-angle region $\left(2 \theta=23.20^{\circ}\right)$, corresponding to a $\pi-\pi$ stacking structure. The lamellar diffraction peak was relatively small $\left(3.67^{\circ}\right)$. In addition, a diffraction peak at $5.69^{\circ}(d=15.51 \AA)$ was detected with a second-order diffraction at $11.17^{\circ}$. Because the distance of the repeating unit of $\mathbf{P} 2$ was estimated to be $15.9 \AA$ using DFT calculations, these diffractions may result from a periodic structure in the main chain direction. Similar observations have been previously reported. ${ }^{42,43}$ P3 exhibited diffractions from both lamellar and stacking structures. 

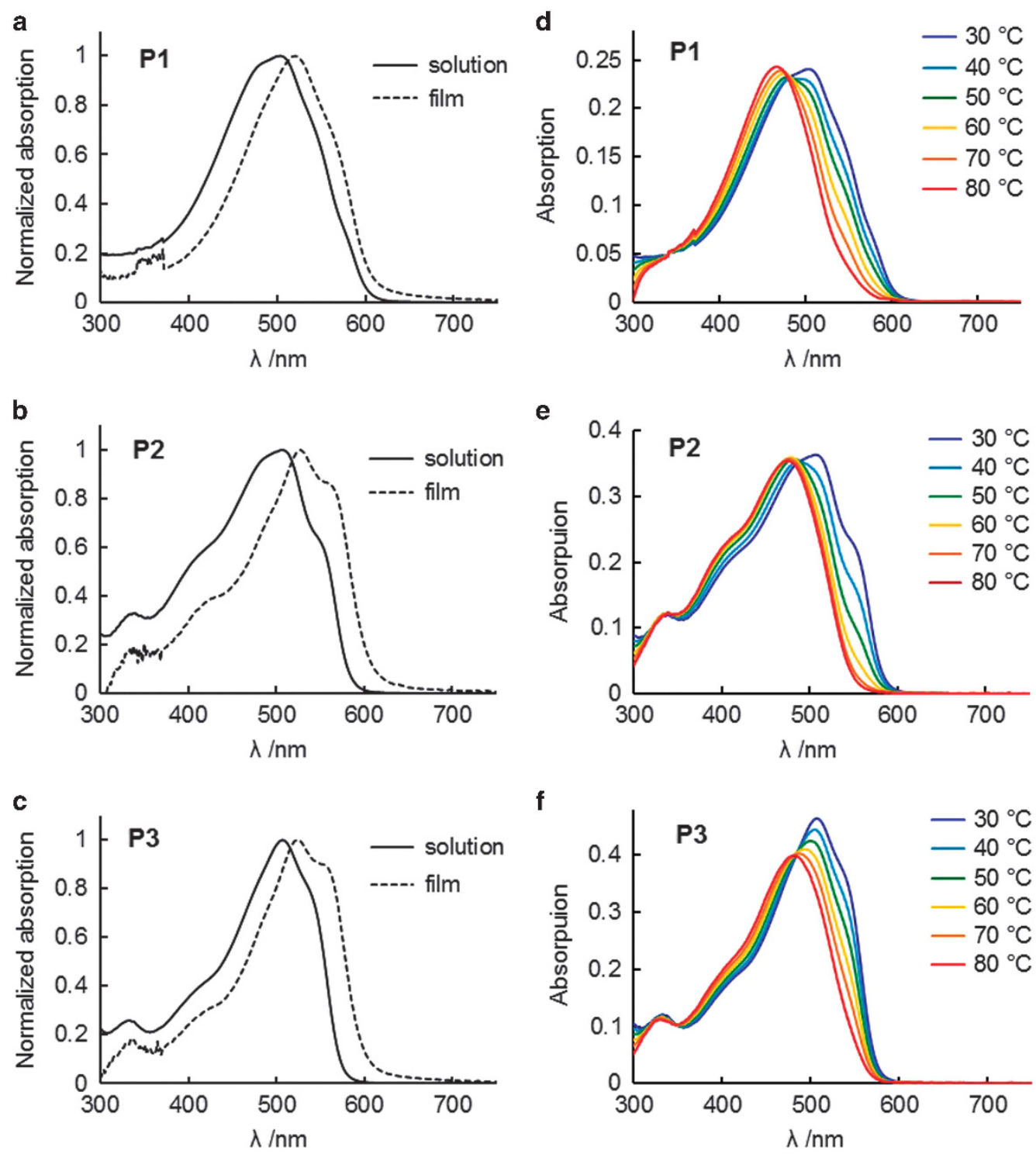

Figure 3 (a-c) UV-Vis absorption spectra of P1-P3 in the solution state (toluene, $30^{\circ} \mathrm{C}, 1.0 \times 10^{-5} \mathrm{M}$ ) and the film state. (d-f) Variable temperature absorption spectra of P1-P3 in toluene $\left(30-80^{\circ} \mathrm{C}, 1.0 \times 10^{-5} \mathrm{M}\right)$.

Table 3 Absorption properties

\begin{tabular}{|c|c|c|c|c|c|}
\hline \multirow[b]{2}{*}{ Polymer } & \multicolumn{2}{|c|}{ Solution ${ }^{a}$} & \multirow{2}{*}{$\begin{array}{c}\text { Calculation }^{\mathrm{b}} \\
\lambda_{\max }, \mathrm{nm}\end{array}$} & \multicolumn{2}{|c|}{ Film } \\
\hline & $\begin{array}{c}\lambda_{\max }, \mathrm{nm} \text { at } \\
30^{\circ} \mathrm{C}\end{array}$ & $\begin{array}{c}\lambda_{\max }, \mathrm{nm} \text { at } \\
80^{\circ} \mathrm{C}\end{array}$ & & $\lambda_{\max }, n m$ & $\lambda_{\text {onset }}{ }^{c}, n m$ \\
\hline P1 & 504 & 466 & 517 & 520 & 602 \\
\hline P2 & 507 & 476 & 498 & 527 & 603 \\
\hline P3 & 507 & 480 & 505 & 523 & 600 \\
\hline
\end{tabular}

aln toluene $\left(1.0 \times 10^{-5} \mathrm{M}\right)$.

${ }^{b}$ Calculated using TD-DFT.

cAbsorption onset.

\section{OPV characteristics}

Because the energy levels of $\mathbf{P} 2$ and $\mathbf{P} 3$ looked promising, these polymers were evaluated as BHJ OPV materials. The BHJ OPVs were fabricated with $\mathrm{PC}_{70} \mathrm{BM}$ as the acceptor material and blend ratios of 1:2 or 1:4 using various solvents (Table 5 and Supplementary Table S2). The OPV with $\mathrm{P} 2: \mathrm{PC}_{70} \mathrm{BM}$ at a $1: 4$ mixing ratio using $\mathrm{CB}$ as the solvent yielded a power conversion efficiency (PCE) of $0.51 \%$ (Entry 1, Table 5). This PCE increased to $1.03 \%$ upon addition of $3 \%$ DIO in the CB solvent (Entry 2, Supplementary Figure S15). The surface morphology of the active layers was evaluated using atomic force microscopy (Figure 6). In contrast to the smooth surface of $\mathbf{P} \mathbf{2}$ (Figure 6a), the surface of the $\mathrm{BHJ}$ film with $\mathbf{P} 2$ and $\mathrm{PC}_{70} \mathrm{BM}$ was rough, indicating substantial phase separation (Figure $6 \mathrm{~b}$ ). The pronounced phase separation reduced the heterojunction interface area for exciton dissociation, which led to the low $J_{\text {sc }}$ of BHJ OPVs. Because the addition of $3 \%$ DIO in the CB solvent decreased the domain size (Figure 6c), the increase in PCE most likely resulted from improvement in phase separation. P3 exhibited a trend similar to that of P2 (Supplementary Figure S16). Owing to the strong intermolecular interactions of the bithiazole units, control of the aggregation behavior is crucial for improvement of PCE in the bithiazole-based polymer materials. 
Model structure

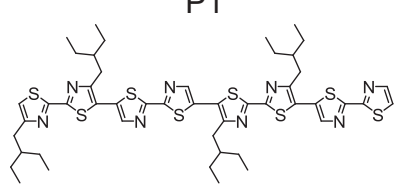

P2

P3

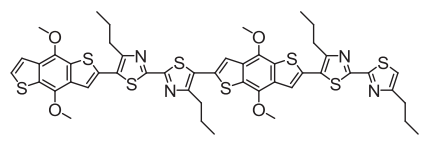

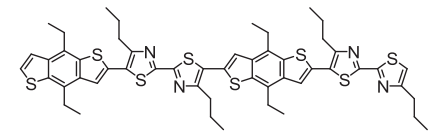

LUMO
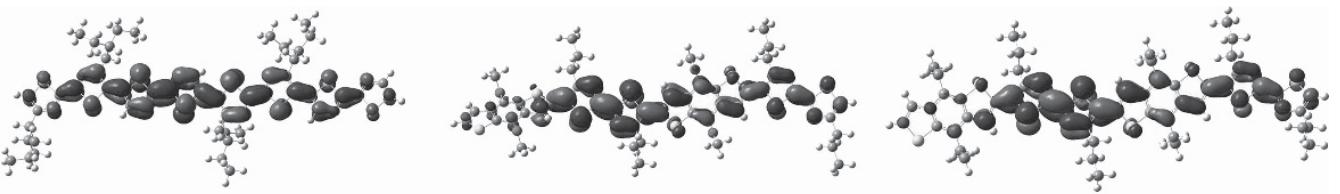

HOMO
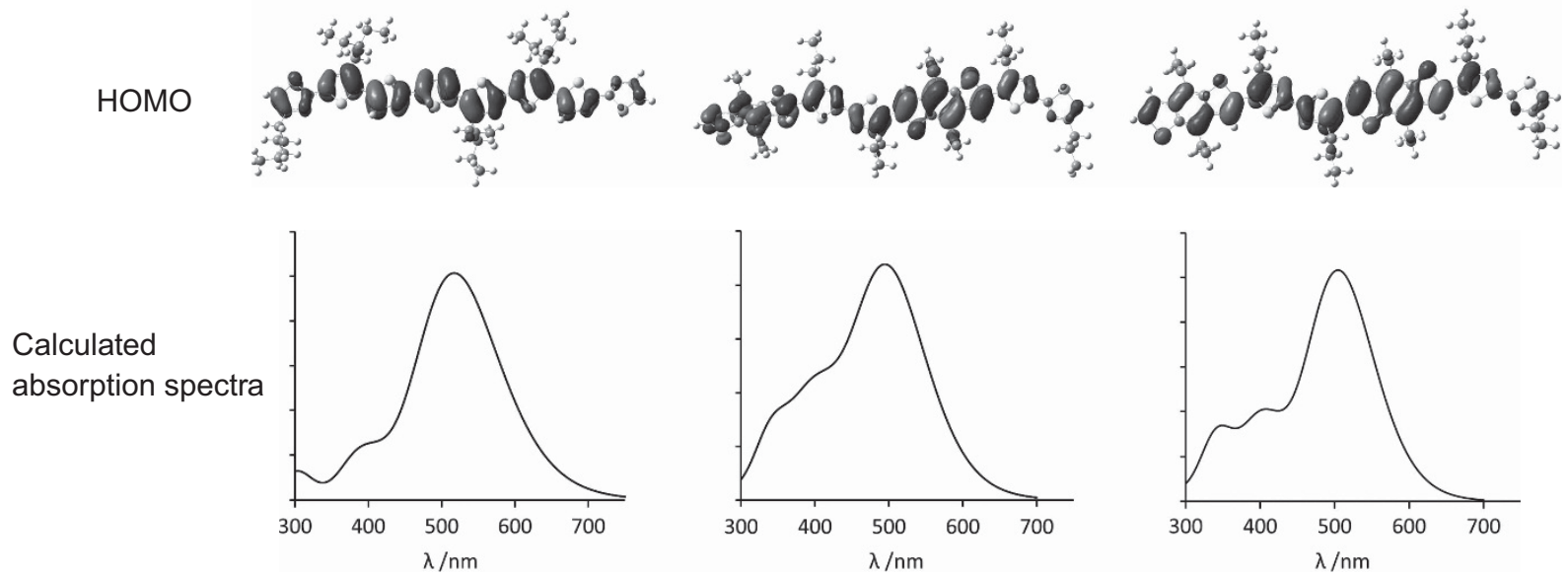

Figure $4 \mathrm{HOMO}$ and LUMO distribution of model compounds for P1-P3 along with the calculated absorption spectra obtained from TD-DFT calculations. A full color version of this figure is available at Polymer Journal online.

Table 4 Physical properties

\begin{tabular}{|c|c|c|c|c|c|}
\hline Polymer & $\mathrm{E}_{g}$ opta, eV & $H O M O^{b}, e V$ & $\angle U M O^{C}, e V$ & $\mathrm{~T}_{d 5^{\mathrm{d}}}{ }^{\circ}{ }^{\circ} \mathrm{C}$ & Diffraction peak $(2 \theta)^{\mathrm{e}}$ \\
\hline P2 & 2.06 & -5.40 & -3.34 & 312 & $3.67,5.69,11.17,23.20$ \\
\hline
\end{tabular}

Abbreviations: HOMO, highest occupied molecular orbital; LUMO, lowest unoccupied molecular orbital.

apptical band gap from the absorption onset in the film state.

bHOMO from photoelectron yield spectroscopy.

CLUMO $=\mathrm{HOMO}+E_{\mathrm{g}} \mathrm{opt}$.

dThe $5 \%$ weight-loss temperatures under an inert atmosphere.

eDiffraction peaks from XRD after annealing at $200^{\circ} \mathrm{C}$.
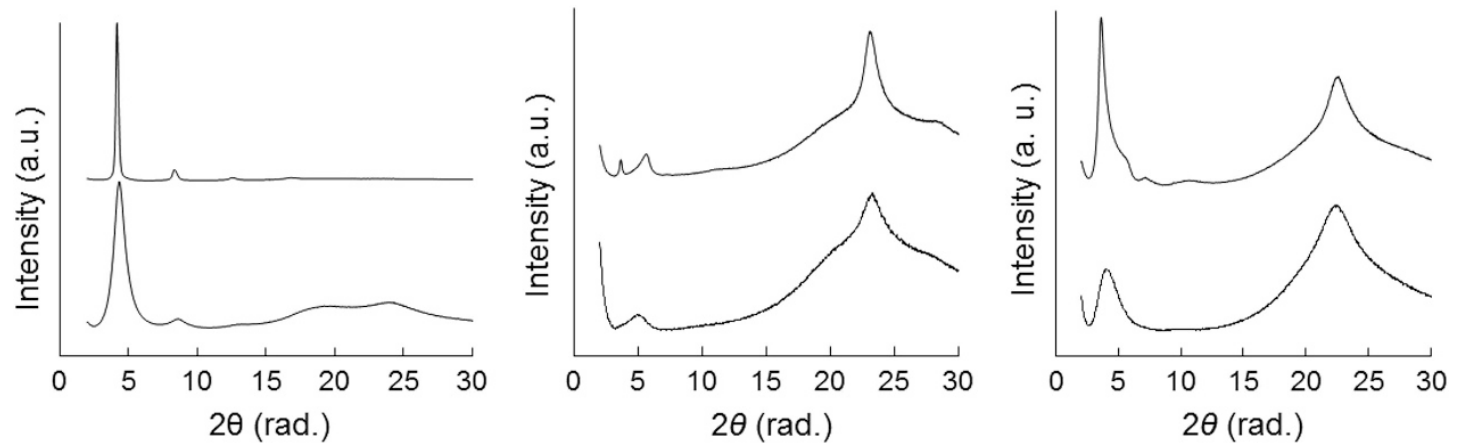

Figure 5 X-ray diffraction patterns of P1-P3 before (bottom) and after annealing (top). 
Table 5 OPV characteristics ${ }^{\mathrm{a}}$

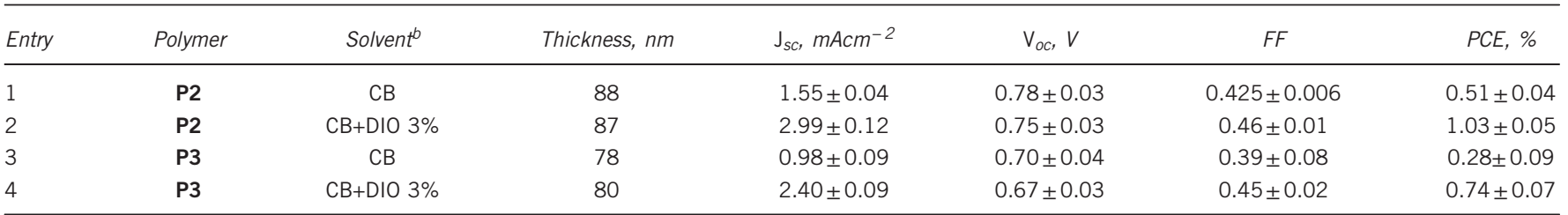

Abbreviations: FF, fill factor; OPV, organic photovoltaic.

The average values with s.ds. were calculated from the results of three or more OPV samples. OPV configuration: ITO/PEDOT:PSS (40 nm)/P2-P3:PC 70 BM (1:4)/LiF (1 nm)/Al (80 nm),

${ }^{\mathrm{b}} \mathrm{Chlorobenzene}(\mathrm{CB})$ and 1,8 -diiodooctane (DIO).

a

P2

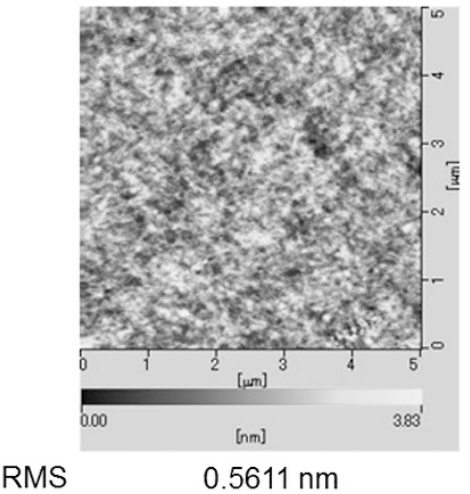

b

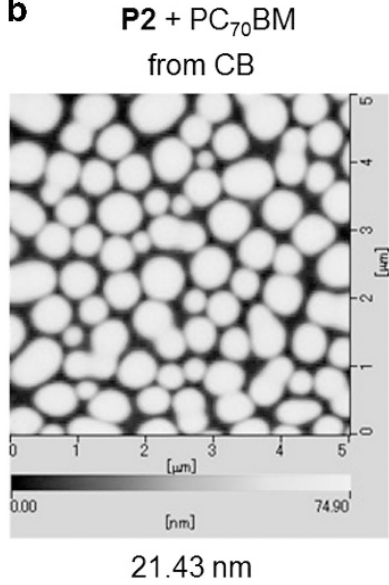

C $\quad \mathbf{P} 2+\mathrm{PC}_{70} \mathrm{BM}$

from $\mathrm{CB}+\mathrm{DIO} 3 \%$

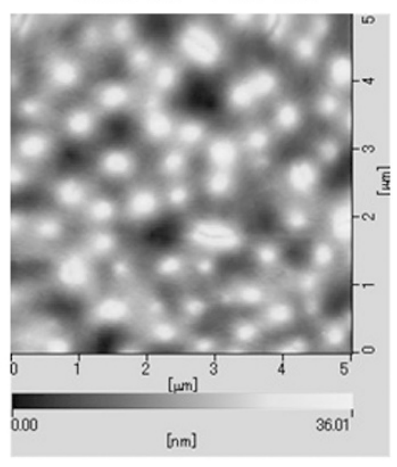

$6.139 \mathrm{~nm}$

Figure 6 AFM images $\left(5 \times 5 \mu \mathrm{m}^{2}\right)$ of (a) P2, (b) P2:PC $70 \mathrm{BM}(1: 4)$ from CB solution, and (c) P2:PC $70 \mathrm{BM}(1: 4)$ from $\mathrm{CB}+\mathrm{DIO} 3 \%$ solution with the root mean square (RMS) roughness values. A full color version of this figure is available at Polymer Journal online.

\section{CONCLUSION}

The investigation of the reaction conditions of the direct arylation polycondensation led to the successful synthesis of bithiazole-based crystalline polymers with low solubilities. The choice of a suitable solvent (that is, $\mathrm{N}, \mathrm{N}$-diethylpropanamide) facilitated smooth coupling reactions along with the prevention of precipitation of the growing polymers as the reaction progressed. The bithiazole-based polymer exhibited aggregation even in the dilute solution state $\left(1 \times 10^{-5} \mathrm{M}\right)$. This aggregation behavior produced high crystallinity, which was confirmed by the X-ray diffraction analysis. Control of aggregation is a key factor for increasing the PCE of the BHJ OPVs with bithiazolebased conjugated polymers. This study expanded the application range of direct arylation polycondensation for the preparation of various crystalline polymers with low solubilities. In addition, the detailed investigation of the structure-property relationships provides insight into the molecular design of conjugated polymer materials.

\section{CONFLICT OF INTEREST}

The authors declare no conflict of interest.

\section{ACKNOWLEDGEMENTS}

We thank the Chemical Analysis Center of University of Tsukuba for the NMR and MALDI-TOF-MS spectral measurements. We also thank Professor Y Nishihara and Professor H Mori of Okayama University for measurement of the high-temperature GPC. This work was supported by the Industrial Technology Research Grant Program in 2011 from New Energy and Industrial Technology Development Organization (NEDO) of Japan and partially supported by a Grant-in-Aid for Young Scientists (B) (15K17922).
1 Lin, Y., Fan, H., Li, Y. \& Zhan, X. Thiazole-based organic semiconductors for organic electronics. Adv. Mater. 24, 3087-3106 (2012).

2 Ando, S., Murakami, R., Nishida, J. I., Tada, H., Inoue, Y., Tokito, S. \& Yamashita, Y. nType organic field-effect transistors with very high electron mobility based on thiazole oligomers with trifluoromethylphenyl groups. J. Am. Chem. Soc. 127, 14996-14997 (2005).

3 Balan, B., Vijayakumar, C., Saeki, A., Koizumi, Y. \& Seki, S. p/n Switching of ambipolar bithiazole-benzothiadiazole-based polymers in photovoltaic cells. Macromolecules 45, 2709-2719 (2012)

4 Liu, J., Zhang, R., Osaka, I., Mishra, S., Javier, A. E., Smilgies, D. M., Kowalewski, T. \& McCullough, R. D. Transistor paint: environmentally stable $N$-alkyldithienopyrrole and bithiazole-based copolymer thin-film transistors show reproducible high mobilities without annealing. Adv. Funct. Mater. 19, 3427-3434 (2009).

5 Kim, D. H., Lee, B. L., Moon, H., Kang, H. M., Jeong, E. J., Park, J., II, Han, K. M., Lee, S., Yoo, B. W., Koo, B. W., Kim, J. Y., Lee, W. H., Cho, K., Becerril, H. A. \& Bao, Z. Liquid-crystalline semiconducting copolymers with intramolecular donor-acceptor building blocks for high-stability polymer transistors. J. Am. Chem. Soc. 131, 6124-6132 (2009)

6 Li, K., Huang, J., Hsu, Y., Huang, P., Lin, J., Ho, K., Wei, K., Lin, H. \& Chu, C. Tunable novel cyclopentadithiophene-based copolymers containing various numbers of bithiazole and thienyl units for organic photovoltaic cell applications. Macromolecules 42, 3681-3693 (2009)

7 Yang, M., Peng, B., Liu, B., Zou, Y., Zhou, K., He, Y., Pan, C. \& Li, Y. Synthesis and photovoltaic properties of copolymers from benzodithiophene and thiazole. J. Phys. Chem. C 114, 17989-17994 (2010).

8 Guo, X., Zhang, M., Huo, L., Cui, C., Wu, Y., Hou, J. \& Li, Y. Poly(thieno[3,2-b] thiophene-alt-bithiazole): a D-A copolymer donor showing improved photovoltaic performance with indene- $\mathrm{C}_{60}$ bisadduct acceptor. Macromolecules 45, 6930-6937 (2012).

9 Carsten, B., He, F., Son, H. J., Xu, T. \& Yu, L. Stille polycondensation for synthesis of functional materials. Chem. Rev. 111, 1493-1528 (2011).

10 Sakamoto, J., Rehahn, M., Wegner, G. \& Schlüter, A. D. Suzuki polycondensation: polyarylenes à la carte. Macromol. Rapid Commun. 30, 653-687 (2009).

11 Huang, J. H., Li, K. C., Chien, F. C., Hsiao, Y. S., Kekuda, D., Chen, P., Lin, H. C., Ho, K. C. \& Chu, C. W. Correlation between exciton lifetime distribution and morphology of bulk heterojunction films after solvent annealing. J. Phys. Chem. C 114, 9062-9069 (2010)

12 Okamoto, K., Zhang, J., Housekeeper, J. B., Marder, S. R. \& Luscombe, C. K. C-H arylation reaction: atom efficient and greener syntheses of $\pi$-conjugated small 
molecules and macromolecules for organic electronic materials. Macromolecules 46, 8059-8078 (2013).

13 Kuwabara, J. \& Kanbara, T. Development of synthetic method for $\pi$ conjugated polymers via direct arylation polycondensation. J. Synth. Org. Chem. Jpn 72, 1271-1278 (2014).

14 Segawa, Y., Maekawa, T. \& Itami, K. Synthesis of extended $\pi$-systems through C-H activation. Angew. Chem. Int. Ed. 54, 66-81 (2015).

15 Wang, Q., Takita, R., Kikuzaki, Y. \& Ozawa, F. Palladium-catalyzed dehydrohalogenative polycondensation of 2-bromo-3-hexylthiophene: an efficient approach to head-totail poly(3-hexylthiophene). J. Am. Chem. Soc. 132, 11420-11421 (2010).

16 Berrouard, P., Najari, A., Pron, A., Gendron, D., Morin, P. O., Pouliot, J. R., Veilleux, J. \& Leclerc, M. Synthesis of 5-alkyl[3,4-c]thienopyrrole-4,6-dione-based polymers by direct heteroarylation. Angew. Chem. Int. Ed. 51, 2068-2071 (2012).

17 Kuwabara, J., Yasuda, T., Choi, S. J., Lu, W., Yamazaki, K., Kagaya, S., Han, L. \& Kanbara, T. Direct arylation polycondensation: a promising method for the synthesis of highly pure, high-molecular-weight conjugated polymers needed for improving the performance of organic photovoltaics. Adv. Funct. Mater. 24, 3226-3233 (2014).

18 Matsidik, R., Komber, H., Luzio, A., Caironi, M. \& Sommer, M. Defect-free naphthalene diimide bithiophene copolymers with controlled molar mass and high performance via direct arylation polycondensation. J. Am. Chem. Soc. 137, 6705 (2015).

19 Lu, W., Kuwabara, J. \& Kanbara, T. Synthesis of 4,4'-dinonyl-2,2'-bithiazole-based copolymers via Pd-catalyzed direct C-H arylation. Polym. Chem. 3, 3217-3219 (2012).

20 Choi, S. J., Kuwabara, J. \& Kanbara, T. Microwave-assisted polycondensation via direct arylation of 3,4-ethylenedioxythiophene with 9,9-dioctyl-2,7-dibromofluorene. ACS Sustain. Chem. Eng. 1, 878-882 (2013).

21 Kuramochi, M., Kuwabara, J., Lu, W. \& Kanbara, T. Direct arylation polycondensation of bithiazole derivatives with various acceptors. Macromolecules 47, 7378-7385 (2014).

22 Lu, W., Kuwabara, J., Kuramochi, M. \& Kanbara, T. Synthesis of bithiazole-based crystalline polymers via palladium-catalyzed direct $\mathrm{C}-\mathrm{H}$ arylation. J. Polym. Sci. Part A Polym. Chem. 53, 1396-1402 (2015).

23 Jung, H., Yu, J., Jeong, E., Kim, J., Kwon, S., Kong, H., Lee, K., Woo, H. Y. \& Shim, H. K. Synthesis and photovoltaic properties of cyclopentadithiophene-based low-bandgap copolymers that contain electron-withdrawing thiazole derivatives. Chem. Eur. J. 16 3743-3752 (2010).

24 Wong, W. Y., Wang, X. Z., He, Z., Chan, K. K., Djurišić, A. B., Cheung, K. Y., Yip, C. T., Ng, A. M. C., Yan, Y. X., Mak, C. S. K. \& Chan, W. K. Tuning the absorption, charge transport properties, and solar cell efficiency with the number of thienyl rings in platinum-containing poly(aryleneethynylene)s. J. Am. Chem. Soc. 129, 14372-14380 (2007).

25 Wang, H., Ding, Y., Lai, Y., Sun, Z., Liu, Y., Jiang, B., Chen, M., Yao, J., Liu, F. \& Russell, T. P. Ethynylene-linked benzo[1,2-b:4,5-b']dithiophene-alt-diketopyrrolopyrrole alternating copolymer: optoelectronic properties, film morphology and photovoltaic applications. J. Mater. Chem. A 3, 12972-12981 (2015).

26 Nanos, J. I., Kampf, J. W. \& Curtis, M. D. Poly(alkylbithiazoles): a new class of variablebandgap, conjugated polymer. Chem. Mater. 7, 2232-2234 (1995).

27 Yamamoto, T., Komarudin, D., Arai, M., Lee, B. L., Suganuma, H., Asakawa, N., Inoue, Y., Kubota, K., Sasaki, S., Fukuda, T. \& Matsuda, H. Extensive studies on $\pi$-stacking of poly(3-alkylthiophene-2,5-diyl)s and poly(4-alkylthiazole-2,5-diyl)s by optical spectroscopy, NMR analysis, light scattering analysis, and X-ray crystallography. J. Am. Chem. Soc. 120, 2047-2058 (1998)
28 Liégault, B., Lapointe, D., Caron, L., Vlassova, A. \& Fagnou, K. Establishment of broadly applicable reaction conditions for the palladium-catalyzed direct arylation of heteroatom-containing aromatic compounds. J. Org. Chem. 74, 1826-1834 (2009).

29 Kuwabara, J., Sakai, M., Zhang, Q. \& Kanbara, T. Mechanistic studies and optimisation of a Pd-catalysed direct arylation reaction using phosphine-free systems. Org. Chem. Front. 2, 520-525 (2015).

30 Rudenko, A. E. \& Thompson, B. C. The effect of amide solvent structure on the direct arylation polymerization (DArP) of 2-Bromo-3-hexylthiophene. J. Polym. Sci. Part A Polym. Chem. 53, 2494-2500 (2015).

31 Wakioka, M., Nakamura, Y., Hihara, Y., Ozawa, F. \& Sakaki, S. A highly efficient catalyst for the synthesis of alternating copolymers with thieno[3,4-c]pyrrole-4,6-dione units via direct arylation polymerization. Macromolecules 47, 626-631 (2014).

32 Kuwabara, J., Yamazaki, K., Yamagata, T., Tsuchida, W. \& Kanbara, T. The effect of a solvent on direct arylation polycondensation of substituted thiophenes. Polym. Chem. 6, 891-895 (2015).

33 Liu, Y., Shi, Q., Ma, L., Dong, H., Tan, J., Hu, W. \& Zhan, X. Copolymers of benzo[1,2$\left.\mathrm{b}: 4,5-\mathrm{b}^{\prime}\right]$ dithiophene and bithiazole for high-performance thin film phototransistors. J. Mater. Chem. C 2, 9505-9511 (2014).

34 Kowalski, S., Allard, S. \& Scherf, U. Scope and limitations of a direct arylation polycondensation scheme in the synthesis of PCPDTBT-type copolymers. Macromol. Rapid Commun. 36, 1061-1068 (2015).

35 Lombeck, F., Matsidik, R., Komber, H. \& Sommer, M. Simple synthesis of P(Cbz-altTBT) and PCDTBT by combining direct arylation with Suzuki polycondensation of heteroaryl chlorides. Macromol. Rapid Commun. 36, 231-237 (2015).

36 lizuka, E., Wakioka, M. \& Ozawa, F. Mixed-ligand approach to palladium-catalyzed direct arylation polymerization: effective prevention of structural defects using diamines. Macromolecules 49, 3310-3317 (2016).

37 Wakioka, M., Nakamura, Y., Montgomery, M. \& Ozawa, F. Remarkable ligand effect of P $\left(2-\mathrm{MeOC}_{6} \mathrm{H}_{4}\right)_{3}$ on palladium-catalyzed direct arylation. Organometallics 34 , 198-205 (2015).

38 Wakioka, M., Ishiki, S. \& Ozawa, F. Synthesis of donor-acceptor polymers containing thiazolo[5,4-d]thiazole units via palladium-catalyzed direct arylation polymerization. Macromolecules 48, 8382-8388 (2015).

39 Braunecker, W. A., Oosterhout, S. D., Owczarczyk, Z. R., Kopidakis, N., Ratcliff, E. L. Ginley, D. S. \& Olson, D. C. Semi-random vs well-defined alternating donor-acceptor copolymers. ACS Macro Lett. 3, 622-627 (2014).

40 Kong, H., Cho, S., Lee, D. H., Cho, N. S., Park, M. J., Jung, I. H., Park, J. H., Park, C. E. \& Shim, H. K. The influence of electron deficient unit and interdigitated packing shape of new polythiophene derivatives on organic thin-film transistors and photovoltaic cells. J. Polym. Sci. Part A Polym. Chem. 49, 2886-2898 (2011).

41 Yasuda, T., Kuwabara, J., Han, L. \& Kanbara, T. Photovoltaic properties of bithiazolebased polymers synthesized by direct $\mathrm{C}-\mathrm{H}$ arylation. J. Photopolym. Sci. Technol. 29, 347-352 (2016).

42 Rivnay, J., Toney, M. F., Zheng, Y., Kauvar, I. V., Chen, Z., Wagner, V., Facchetti, A. \& Salleo, A. Unconventional face-on texture and exceptional in-plane order of a high mobility n-type polymer. Adv. Mater. 22, 4359-4363 (2010).

43 Zhang, X., Bronstein, H., Kronemeijer, A. J., Smith, J., Kim, Y., Kline, R. J., Richter, L. J., Anthopoulos, T. D., Sirringhaus, H., Song, K., Heeney, M., Zhang, W., McCulloch, I. \& DeLongchamp, D. M. Molecular origin of high field-effect mobility in an indacenodithiophene-benzothiadiazole copolymer. Nat. Commun. 4, 2238 (2013).

Supplementary Information accompanies the paper on Polymer Journal website (http://www.nature.com/pj) 